\title{
Effect of Different Weed Control Practices On Proximate Composition, Nutrient Concentration and Uptake of Maize (Zea Mays L.)
}

\author{
Omovbude, Sunday ${ }^{1}$, Oroka, Frank $\mathrm{O}^{2}$. And Udensi, Ekea Udensi ${ }^{1}$ \\ ${ }^{I}$ Department of Crop and Soil Science, University of Port Harcourt, East West Road, Choba P.M.B, 5323 Port \\ Harcourt, Nigeria \\ ${ }^{2}$ Department of Agronomy, Delta State University, Asaba Campus, Nigeria
}

\begin{abstract}
A field experiment was conducted during 2004 and 2005 cropping seasons to determine effect of different weed control practices on proximate composition, nutrient concentration and nutrient uptake of maize (Zea maysL.) at the Teaching and Research Farm of Ambrose Alli University, Ekpoma, Nigeria. Seven treatments were used for the experiment, viz no weeding (control), Primextra (3.0kg a.i./ha), mulching (wood shavings), one- hoe weeding at 3 weeks after planting (WAP), two hoe-weedings at 3 and 7 WAP, cover cropping with melon minus hoe-weeding, cover-cropping with melon plus one hoe-weeding at 3 WAP. The seven treatments were laid out in randomized complete block design with four replicates. Results showed that mulched plot with wood shavings had the lowest weed density and highest proximate composition, grain nutrient concentration, ear leaf concentration and nutrient uptake followed by Primextra treated plot .The study recommends that small holder farmers to adopt mulching technique with wood shaving to improve the nutritional quality of maize grain since it does not involve any technical rigor besides signifying a non-chemical weed control.
\end{abstract}

Key words: maize, nutrient concentration, nutrient uptake, proximate composition, weed density

\section{Introduction}

Maize (Zea mays L.) belongs to the grass family of plant known as Poaceae . In Nigeria ,it is grown in several zones from coastal swamps of the south to the dry savanna lands of the north [1] It is an important food, fodder and industrial crop grown both commercially and at subsistence level in Nigeria [2]. Proximate composition of the grains by [3] showed that crude protein ranged from 10.67 to $11.25 \%$, lipid (4.17 to 5\% ), crude fibre (2.07 to $2.97 \%$ ), and carbohydrate (65.63 to 70.23\%) while [4] noted that crude ash ranged from 1.4 and $3.3 \%$. The mineral composition of the maize grain consists of $1.88 \%$ nitrogen, $0.41 \%$ phosphorous, $0.38 \%$ potassium, $0.10 \%$ calcium and $0.12 \%$ magnesium [5]. Despite the usefulness of this crop, its production is hampered as result of weed infestation. In Nigeria, adverse weed infestation in maize fields contributed to drastic reduction of maize yield [6]. Yield loss as result of weed infestation in maize had been reported by several researchers. For instance, [7] reported yield of 51-100\% while [ 8] reported 60-81\% In maize, weeds are controlled using biological, cultural, , chemical, preventive and integrated management practices. Over the years weed control in maize by these various practices had been geared toward yield increase of the grain without paying too much attention on its proximate composition, nutrient concentration in the ear leaf and the grain, and nutrient uptake by these various weed control practices. Hence the objective of study were to determine the effect of different weed control practices on proximate composition, nutrient concentration and uptake of maize.

\section{Materials and Methods}

A field experiment was conducted in 2004 cropping season and repeated in 2005 at the Teaching and Research Farm of Ambrose Alli University ( $6^{\circ} 45 \mathrm{~N}$ and longitude $6^{\circ} 8 \mathrm{E} ; 313 \mathrm{~m}$ above sea level) in the forest savanna transition zone of Nigeria. The total rainfall in 2004 and 2005 were $1786.6 \mathrm{~mm}$ and $2176.7 \mathrm{~mm}$ respectively. The rainfall data were obtained at Edo State Agricultural Development Project (EADP), Irrua substation. Soil samples were randomly collected from 15 spots $(0-15 \mathrm{~cm}$ depth) over the entire field using auger before the commencement of the experiment. The samples were bulked and mixed thoroughly for analysis. The characteristics of the soil used in 2004 were: nitrogen: $1.07 \mathrm{~g} / \mathrm{kg}$ phosphorous: $15.40 \mathrm{mg} / \mathrm{kg}$, potassium: $0.27 \mathrm{cmol} / \mathrm{kg}$, calcium:5.04 $\mathrm{cmo} / \mathrm{kg}$, magnesium: $2.01 \mathrm{cmol} / \mathrm{kg}$, carbon: $15.70 \mathrm{~g} / \mathrm{kg}$ pH $\left(\mathrm{H}_{2} \mathrm{O}, 1: 1\right)$ : 5.70 , exchangeable acidity: $0.40 \mathrm{cmol} / \mathrm{kg}$ and effective cation exchange capacity (ECEC): $8.00 \mathrm{cmol} / \mathrm{kg}$. The characteristics of the adjacent soil used in 2005 were as follow:nitrogen: $1.06 \mathrm{~g} / \mathrm{kg}$, phosphorous: $15.20 \mathrm{mg} / \mathrm{kg}$, potassium: $0.28 \mathrm{cmol} / \mathrm{kg}$, calcium5.05 $\mathrm{cmol} / \mathrm{kg}$, magnesium:3.14mg/kg, carbon: $16.70 \mathrm{~g} / \mathrm{kg}, \mathrm{pH}\left(\mathrm{H}_{2} \mathrm{O}, 1: 1\right): 5.40$, exchangeable acidity: $0.40 \mathrm{cmol} / \mathrm{kg}$ and Effective Cation Exchange Capacity (ECEC): $9.16 \mathrm{cmol} / \mathrm{kg}$.. 
Land preparation was done manually. Each plot size was $3 \mathrm{~m}$ x $4 \mathrm{~m}$ with an alley way of $1 \mathrm{~m}$ among plots and $1 \mathrm{~m}$ between replicates. There were thus, a total of 28 plots occupying an experimental area of $27 \mathrm{~m}$ $\mathrm{x} 19 \mathrm{~m}\left(514 \mathrm{~m}^{2}\right)$ approximately $0.05 \mathrm{ha}$. There were seven treatments involved in the experiment, namely: noweeding (control), Primextra ${ }^{\circledR}$ (3.0kga.i./ha), mulching (wood shavings), one hoe weeding (3WAP), Two hoeweeding ( 3 and7WAP), Melon cover - crop minus hoe- weeding and melon cover-crop plus one hoe weeding at3WAP. The treatments were arranged in a complete block design (RCBD) with four replicates. A plant spacing of $75 \mathrm{~cm} \times 25 \mathrm{~cm}$ was used in each cropping season. Two seeds of maize (cultivar DMRESR - W, obtained the International Institute of Tropical Agriculture (IITA) were planted per hole and thinned to one seedling per stand at 2WAP, giving a population density of 53, 333 plants/ha. One day after planting, four plots were sprayed with Primextra ${ }^{\circledR}$ at $3.0 \mathrm{~kg}$ a.iha ${ }^{-1}$ using a hand operated CP3 knapsack sprayer calibrated to deliver approximately $250 \mathrm{lha}^{-1}$ spray volume at a pressure of $210 \mathrm{kpa}$ with red poliject nozzle (swath width $1 / 2 \mathrm{~m}$ ). A local variety of melon (Colocynthus vulgaris L.) was planted within the alleys of maize, planting the same day in each of the cropping seasons. Three seeds of melon were planted per hole at a spacing of $50 \mathrm{~cm} \mathrm{x} 30 \mathrm{~cm}$ giving

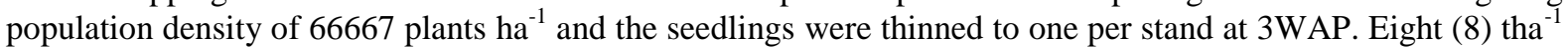
of wood shavings, in each of the cropping seasons, were weighed with a spring balance fixed to a horizontal bar supported on three $1.5 \mathrm{~m}$ fork - sticks, were uniformly spread over the appropriate treatment plots the same day maize was sown. The first hoe-weeding for sole maize/melon inter-crop was carried out at $3 \mathrm{WAP}$ in each season. Three days after the first weeding urea fertilizer containing $46 \%$ Nitrogen was applied at the rate of $39.56 \mathrm{~kg} \mathrm{~N} \mathrm{ha}^{-1}$ and $40.48 \mathrm{~kg} \mathrm{~N} \mathrm{ha}^{-1}$ in 2004 and 2005 respectively to make up the critical level of nitrogen. These were carried out because the level of nitrogen in the soil was inadequate compared to the critical level of $1.5 \mathrm{gkg}^{-1}$ [9] [10]. The second weeding was carried out at 7WAP in sole maize plots only. Data of common weeds present at the experimental site before the trials in both 2004 and 2005 cropping seasons were estimated by using $0.5 \times 0.5 \mathrm{~m}$ quadrats. The weeds were visually counted and identified [11] and classified based on growth cycle and habit. Level of weed density was classified into three as follows: $[+]=$ low density; $[++]=$ medium density and $[+++]=$ high density. The weed density at present at the various intervals of sampling during the experimentation was extrapolated by the quadrat technique. Two ear leaf samples were randomly selected from the centre row of each plot at mid silk and oven dried at $80^{\circ} \mathrm{C}$ for $24 \mathrm{hrs}$. for the determination of nutrient concentration $(\mathrm{N}, \mathrm{P}, \mathrm{K}, \mathrm{Mg}, \mathrm{Ca}$ and $\mathrm{Na}$ ) using the methods described by [12] thereafter the Nutrient uptake was derived from the product of the dry matter and concentration (\%) in leaf tissues. Nutrient concentration ( $\mathrm{N}, \mathrm{P}, \mathrm{K}, \mathrm{Mg}, \mathrm{Ca}$ and $\mathrm{Na}$ ) and Proximate composition ( lipid crude protein, crude ash, crude fiber and carbohydrate) of the grains were also determined by [12] method .

\section{Weed present at experimental site before planting}

\section{Results and Discussion}

Common weeds at the experimental site before the trial in 2004 and 2005 cropping seasons are presented in Table1.The most dominant weed species were: Chromoleana odorata Kings \& Robinson, Euphorbia heterophylla L., Euphorbia hirta L Calopogonium mucunoides Desv, Panicum maximum Jacq. Nine weeds family were identified of which Poaceae was the most common (23.08\%) followed by Asteraceae $(19.23 \%)$, and cyperaceae $(15.38 \%)$ in both years.

\section{Weed density}

The effect of weed control practices on weed density of maize is presented in Table2. The weed density differed significantly $\mathrm{p}<0.05$ throughout the sampling periods. Low weed density were recorded at 3 WAP under the various weed control practices in both years except in Primextra treated and mulch plots where the weeds were significantly considerably lower. At the other sampling periods the no weeding differed significantly from other treatments by having the highest weed population. Weed population was superior at $12 \mathrm{WAP}$ with the no weeding plot producing the highest weed density and mulch plot the lowest. The probable reason for high weed population in no weeding plots in both cropping season could be attributed to lack of weed control measures when compared with others methods of weed control. [13] noted that the higher weeds density in weedy check plots may be attributed to the open soil surface and niches available to weeds for free and aggressive growth. The lower weed density recorded in mulched plot might be attributed to its ability to smother weeds. [14] noted that very little weed growth occurs under the mulch as the mulches prevent penetration of light or exclude certain wavelengths of light that are needed for the weed seedlings to grow. Good weed control recorded in Primextra treated plots may be attributed to its higher herbicidal activity. This finding is also in a line with that of [15] who reported reduced weed infestation in herbicide treated plot of maize in comparison with the control plot 


\section{Proximate composition of the grain}

The effect of different weed control practices on proximate composition in maize grain is presented in Table3. There was significant difference $(\mathrm{P}<0.05)$ among the weed control practices on the proximate composition of the grain in comparison to no weeding (control) in both cropping seasons. In 2004, crude protein ranged from 11.62 to $14.44 \%$ while in 2005 , it ranged from 13.60 to $14.43 \%$. The highest level of crude protein was produced in both years on plots that were mulched with wood shaving while the lowest were from no weeding plots. The percentage protein fell within the range of $10.67-11.25$ of maize grain in Nigeria as reported by [3].The lipid content differed significantly in both cropping seasons. In 2004, the lipid content ranged from 4.56 to $4.86 \%$ plot while in 2005 , it ranged from 4.43 to $4.84 \%$. In both years the mulched plot had the highest lipid content while the un weeded plot had the lowest. The percentage lipid fell within the range of $4.17-5.0$ [3]

Crude ash ranged from 2.70 to $2.91 \%$ in 2004 while it ranged from 2.64 to $2.85 \%$ in 2005. In 2004, the highest crude protein content $(2.91 \%)$ was produced in wood shaving plot which was statistically at par with Primextra ${ }^{\circledR}$ treated plot $(2.87 \%)$ while the lowest $(2.70 \%)$ was produced in no weeding plot which was at par with melon cover minus no hoe weeding $(2.71 \%)$. In 2005 , the highest level of crude ash $(2.85 \%)$ was produced in mulched plot but at par with that of Primextra ${ }^{\circledR}$ treated plots $(2.83 \%)$ while the lowest was in no weeding plot $(2.64 \%)$. In both years the percentage crude ash fell within the range of $1.4-3.3 \%$ [4]. Crude ranged from 2.40 to $2.80 \%$ in 2004 while in 2005 it ranged from 2.35 to $2.80 \%$. The highest crude fibre content $(2.80 \%)$ was in wood shaving plot in 2004 while the lowest was in no weeding plot $(2.40 \%)$ which was at par with melon cover plot without weeding (2.43\%). In 2005, wood shaving plot had the highest crude fibre content while no weeding plot had the lowest. The Crude fibre fell within the range of $2.07-2.97 \%$ [3]. Carbohydrate content ranged from 64.71 to $79.28 \%$ in 2004 while in 2005 it ranged from 64.31 to $79.21 \%$. In both cropping seasons, the highest carbohydrate content was recorded in plots mulched with wood shavings while the lowest was on no weeding plots. The carbohydrate content fell within the range $65.63-70.23 \%$ ) [3]. Carbohydrate value by difference weed control practices was higher than others proximate substances and this confirmed that maize grain is mainly of energy giving food.

Generally, the lowest values of food content in maize grain ( lipid crude protein, crude ash, crude fibre and carbohydrate) recorded in no weeding plots might be attributed to its high weed density .The high weed population present in the no weeding plots compete with maize plants for growth resources such as water, light and nutrients The results agreed with findings of [16] who noted reduced food content on pea (Pisum sativum L.) plants in an weedy plots. On the other hand, the high food content in maize crop could be attributed to remarkable weed control measures by other weed control practices particularly by plots mulched with wood shavings and that of Primextra treated

\section{Ear Leaf Dry Weight And Nutrient Concentration}

The effect of different weed control practices on ear leaf dry weight and nutrient concentration in ear leaf of maize is presented in Table 4 . The ear dry weight differed significantly among the various weed control treatments. In 2004, dry weight of ear leaf ranged from 1063.66 to $1973.32 \mathrm{~kg} / \mathrm{ha}$ while in 2005 , it ranged from 978.66 to $1946.65 \mathrm{~kg} / \mathrm{ha}$. In both cropping seasons the highest ear leaf dry weight was recorded in plots mulched with wood shavings while the lowest was in the no weeding plots. In 2004 , N ranged from 0.41 to $2.79 \%$ while in 2005 , it ranged from 0.40 to $2.61 \%$. In 2004, wood shaving plots had the highest $\mathrm{N}$ content while the no weeding plot had the lowest $(0.40 \%)$ statistically at par with melon cover -crop (-Hoe-weeding) $(0.50 \%)$ One hoe-weeding at 3WAP (0.79\%), melon cover -crop+Hoeweeding at (3WAP) $(0.80 \%)$. In 2005, the highest N content was recorded in wood shaving ( $2.61 \%$ ) which was statistically at par with Primextra treated plot $(1.90 \%)$ while the lowest was in the no weeding $(0.40 \%)$ melon cover -crop (-Hoe-weeding) $(0.49 \%)$ one hoeweeding at 3 WAP $(0.76 \%)$, melon cover -crop+Hoeweeding at (3WAP) $(0.92 \%)$,

The $\mathrm{N}$ content fell within the range of $2.25-3.30 \%$ established by [17].The $\mathrm{P}$ content ranged from 0.20 to $0.38 \%$ in 2004 while in 2005 , it ranged from 0.19 to $0.37 \%$. P content was higher in plots mulched with wood shaving in both cropping seasons and lower in no weeding plots. The P content fell slightly above the ranged of $0.18-0.32 \%$ [17]. There were no significant differences ( $p>0.05)$ among the various weed control practices in the levels of $\mathrm{K}$ content in both cropping seasons. Ca content ranged from 0.22 to $0.50 \%$ in 2004 while in 2005 it ranged from 0.21 to $0.48 \%$. Plots mulched with wood shavings had the highest level of Ca while the lowest was in the no weeding plots. The Ca content fell slightly above the ranged of $0.40-0.80 \%$ [ 17 ]. Mg content ranged from 0.23 to $0.49 \%$ in 2004 while in 2005, it ranged from 0.20 to $0.47 \%$. In both years the highest level of $\mathrm{Mg}$ was in mulched plot while the lowest was in no weeding plots. $\mathrm{Mg}$ content fell slightly above $0.13-0.25 \%$ [17]. Na content ranged from 0.37 to $1.18 \%$ while in 2005 , it ranged from 0.36 to $1.17 \%$. The highest level of $\mathrm{Na}(1.18$ and $1.17 \%)$ was in plot mulched with wood shavings which was at par with plot treated with Primextra( 0.79 and $0.78 \%$ ), plot hoe weeded twice at 3 and 7WAP (0.71 and $0.70 \%)$ and Melon cover -crop plus one Hoeweeding at (3WAP) ( 0.67 and $0.66 \%$ ) while the lowest was in no weeding plot 0.37 
and $0.36 \%$ )which was at par with melon cover -crop (-Hoe-weeding, $(0.38$ and $0.38 \%)$ one hoe-weeding at 3 WAP $(0.47$ and $0.46 \%)$ and melon cover -crop+Hoeweeding at (3WAP) (0.67 and 0.66\%) in 2004 and 2005 cropping seasons respectively

\section{Nutrient uptake in ear leaf}

The effect of different weed control practices on nutrient uptake of ear leaf of maize is in Table5. The nutrient uptake differed significantly among the various weed control practices in both cropping seasons. In 2004, N uptake ranged from 4.36 to $55.06 \mathrm{~kg} / \mathrm{ha}$ while in 2005 , it ranged from 3.95 to $54.12 \mathrm{~kg}$./ha. In 2004, plots that were mulched with wood shavings had the highest $\mathrm{N}$ uptake while plots that were unweeded had the lowest $(4.36 \mathrm{~kg} / \mathrm{ha})$ but statistically at par with that of melon cover -crop (-Hoe-weeding) $(5.36 \mathrm{~kg} / \mathrm{ha})$, one hoe-weeding $3 \mathrm{WAP}(9.10 \mathrm{~kg} / \mathrm{ha})$, melon cover -crop+Hoeweeding (3WAP) $(10.53 \mathrm{~kg} / \mathrm{ha})$, two hoe-weedings at $3 \& 7 \mathrm{WAP}$ $(18.62 \mathrm{~kg} / \mathrm{ha})$. In 2005 , plots that were mulched with wood shavings had the highest $\mathrm{N}$ uptake while plots that were unweeded had the lowest $(3.95 \mathrm{~kg} / \mathrm{ha})$ but statistically at par with that of melon cover -crop (-Hoeweeding) $(4.97 \mathrm{~kg} / \mathrm{ha})$, one hoe-weeding at $3 \mathrm{WAP}(8.96 \mathrm{~kg} / \mathrm{ha})$ melon cover -crop+Hoeweeding (3WAP) (10.03kg/ha). In 2004, P uptake ranged from 2.13 to $7.50 \mathrm{~kg} / \mathrm{ha}$ while in 2005 , it ranged from 1.86 to 7.20 $\mathrm{kg} / \mathrm{ha}$. In 2004, plots that were mulched with wood shavings had the highest P uptake $(7.50 \mathrm{~kg} / \mathrm{ha})$ which was at par with that of Primextra treated plot $(7.06 \mathrm{~kg} / \mathrm{ha})$ while plots that were unweeded had the lowest $2.13 \mathrm{~kg} / \mathrm{ha}$ but statistically at par with that of melon cover -crop (-Hoe-weeding) $(2.47 \mathrm{~kg} / \mathrm{ha})$. In 2005 , plot mulched with wood shavings had the highest P uptake $(7.50 \mathrm{~kg} / \mathrm{ha})$ which was at par with that of Primextra treated plot $(6.76 \mathrm{~kg} / \mathrm{ha})$ while the lowest was in no weeding $\operatorname{plot}(1.86 \mathrm{~kg} / \mathrm{ha})$ which was at par with that of melon cover -crop (-Hoeweeding) $(2.23 \mathrm{~kg} / \mathrm{ha})$. In $2004, \mathrm{~K}$ uptake ranged from 21.06 to $46.96 \mathrm{~kg} / \mathrm{ha}$ while in 2005 ranged from 19.08 to $46.33 \mathrm{~kg} / \mathrm{ha}$. In $2004, \mathrm{~K}$ uptake was higher $(46.96 \mathrm{~kg} / \mathrm{ha})$ in mulched plot but statistically at par with Primextra plot(45.33 kg/ha), two hoe-weedings at3 \&7WAP $(39.96 \mathrm{~kg} / \mathrm{ha})$, while lower in no weeding $\operatorname{plot}(21.06 \mathrm{~kg} / \mathrm{ha})$, but at par with that of melon cover -crop (-Hoe-weeding) $(21.44 \mathrm{~kg} / \mathrm{ha})$, melon cover crop+Hoeweeding (3WAP) $(27.52 \mathrm{~kg} / \mathrm{ha})$. In 2005 , K uptake was higher in mulched plot $(46.33 \mathrm{~kg} / \mathrm{ha})$ which was at par with Primextra treated plot $(.44 .40 \mathrm{~kg} / \mathrm{ha})$, two hoe-weedings at 3 \&7WAP $(39.26 \mathrm{~kg} / \mathrm{ha})$, while the lowest was in no weeding plot $(19.08 \mathrm{~kg} / \mathrm{ha})$, at par with that of Melon cover -crop (-Hoe-weeding) $(19.96 \mathrm{~kg} / \mathrm{ha}$ ), One hoe-weeding 3WAP (24.04kg/ha), melon cover -crop+Hoeweeding (3WAP)( $26.51 \mathrm{~kg} / \mathrm{ha})$. In 2004, Ca uptake ranged from 2.34 to $9.87 \mathrm{~kg} / \mathrm{ha}$ while in 2005 it ranged from 2.06 to $9.34 \mathrm{~kg} / \mathrm{ha}$.Ca content in 2004 was higher in plot mulched with wood shavings while lower in no weeding $(2.34 \mathrm{~kg} / \mathrm{ha})$ which was at par with that of melon cover - crop (-Hoe-weeding) $(2.47 \mathrm{~kg} / / \mathrm{ha})$ In 2005 , Ca uptake was higher in in mulched plot while it was lower in no weeding $(2.06 \mathrm{~kg} / \mathrm{ha})$, but at par with that of Melon cover -crop (-Hoe-weeding) $(2.23 \mathrm{~kg} / \mathrm{ha})$. In 2004, Mg content ranged from 2.44 to $9.67 \mathrm{~kg} / \mathrm{ha}$ while in 2005 , it ranged from 1.96 to $9.15 \mathrm{~kg} / \mathrm{ha}$. In 2004 , the highest $\mathrm{Mg}$ uptake was in mulched plot while the lower was in no weeding. $\mathrm{Mg}$ uptake in 2005 was higher in mulched plot and lower in no weeding $(1.96 \mathrm{~kg} / \mathrm{ha})$ which was statistically the same with that of Melon cover crop (-Hoe-weeding)( 2.23kg/ha). In 2004, Na content ranged from 3.94 to $23.29 \mathrm{~kg} / \mathrm{ha}$ while in 2005 it ranged from 3.52 to $22.78 \mathrm{~kg} / \mathrm{ha}$. The highest $\mathrm{Na}$ uptake in 2004 was in mulched $\operatorname{plot}(23.29 \mathrm{~kg} / \mathrm{ha})$ which was at par with Primextra treated plot $(23.29 \mathrm{~kg} / \mathrm{ha})$, two hoe-weedings $3 \& 7 \mathrm{WAP}(13.52 \mathrm{~kg} / \mathrm{ha})$ and the lowest in no weeding $(3.94 \mathrm{~kg} / \mathrm{ha})$ which was at par with one hoe-weeding $3 \mathrm{WAP}(5.65 \mathrm{~kg} / \mathrm{ha})$ Melon cover -crop (-Hoeweeding) (4.07kg/ha) and Melon cover -crop+Hoeweeding (3WAP) $(8.87 \mathrm{~kg} / \mathrm{ha})$. In 2005, the highest Na uptake was in mulched plot $(22.78 \mathrm{~kg} / \mathrm{ha})$ which was at par with Primextra treated plot $(15.06 \mathrm{~kg} / \mathrm{ha})$, Two hoeweedings 3 \&7WAP $(13.15 \mathrm{~kg} / \mathrm{ha})$ while the lowest was in no weeding $(3.52 \mathrm{~kg} / \mathrm{ha})$ which was at par with melon cover - crop (-Hoe-weeding) $(3.85 \mathrm{~kg} / \mathrm{ha})$ One hoe-weeding at $3 \mathrm{WAP}(5.42 \mathrm{~kg} / \mathrm{ha})$ and melon cover crop+Hoeweeding (3WAP) $(8.49 \mathrm{~kg} / \mathrm{ha})$ and two hoe-weedings at $3 \& 7 \mathrm{WAP}(13.15 \mathrm{~kg} / \mathrm{ha})$. Nutrient uptake plays a fundamental role in plant growth and development as its provides the essential elements to plants. Generally, all the weed control practices increased the nutrient uptake of maize when compared to no weeding plots. The highest nutrients uptake were in mulched and Primextra treated plots. The probable reason for the high uptake of nutrients might be due to lesser competition for growth resources between weeds and maize plants. This finding is in agreement with that of [18] who noted higher uptake of nutrients by various weed management strategies in maize.

\section{Nutrient concentration in the grain}

The effect of different weed control practices on nutrient concentration in maize grain is presented in Table 6. The nutrient concentration of the grain differed significantly among the various weed control practices in both cropping seasons. In 2004, N ranged from 2.40 to $2.92 \%$ while in 2005 , it ranged from 2.39 to $2.91 \%$. In 2004, plots that were mulched with wood shavings had the highest $\mathrm{N}$ while plots that were unweeded had the lowest $(2.40 \%)$ but statistically at par with that of melon cover -crop (-Hoe-weeding) (2.42\%.) In 2005, the highest $\mathrm{N}$ was in mulched plots while the lowest was in the un weeded plots. $\mathrm{N}$ levels in both years were below the limit of $1.88 \%$ established by [5]. In 2004, P content ranged from 0.19 to $0.27 \%$ while in 2005 , it ranged 
from 0.18 to $0.26 \%$. In 2004, the highest $\mathrm{P}$ was in mulched plot $(0.27 \%)$ which was at par with Primextra treated plot $(0.26 \%)$ while the lowest was in no weeding plot. In 2005 , the highest $\mathrm{P}$ was in mulched plot $(0.26 \%)$ which was at par with Primextra treated plot $(0.25 \%)$ while the lowest was in no weeding plot. The P levels were below the limit of $0.41 \%$ [5]. In 2004, $\mathrm{K}$ content ranged from 0.18 to $0.25 \%$ while in 2005 it ranged from 0.17 to $0.24 \%$.In both years, the highest $\mathrm{K}$ content was in mulched plot while the lowest was in no weeding plot. K levels were below the limit of $0.38 \%$ [5]. Ca level ranged from 0.27 to $0.36 \%$ while in 2005 it ranged from 0.26 to $0.34 \%$. In both years, the highest Ca was in mulched plot while the lowest was in no weeding plot. Ca level was above the limit of $0.10 \%$ [5]. In 2004, $\mathrm{Mg}$ ranged from 0.10 to $0.17 \%$ while in 2005 it ranged from 0.09 to $0.16 \%$. The highest level of $\mathrm{Mg}$ in both years was in mulched plot while the lowest in no weeding. $\mathrm{Mg}$ level was above the limit of $0.10 \%$ [5]. In 2004, Na level ranged from 0.19 to $0.26 \%$ while in 2005 it ranged from 0.18 to $0.25 \%$. In both years, the highest Na content was in mulched plot while the lowest was in no weeding plot.

\section{Conclusion}

The results of this study had shown that lowest weed density was obtained under plot mulched with wood shavings. The mulched plot also had the highest proximate composition, grain nutrient concentration, ear leaf concentration and nutrient uptake followed by Primextra treated plot The study recommends that small holder farmers to adopt mulching technique with wood shaving to improve the nutritional quality of maize grain since it does not involve any technical rigor besides signifying a non-chemical weed control.

Table1. Common weeds at the experimental site before the trial in 2004 and 2005 cropping seasons

\begin{tabular}{|c|c|c|c|c|}
\hline \multirow[t]{2}{*}{ Family } & \multirow[t]{2}{*}{ Weed species } & \multirow[t]{2}{*}{ Growth form } & \multicolumn{2}{|c|}{ Density } \\
\hline & & & 2004 & 2005 \\
\hline Amaranthaceae & Amaranthus spinosus L & $\mathrm{ABL}$ & ++ & ++ \\
\hline Amaranthaceae & Amaranthus viridis $\mathrm{L}$ & $\mathrm{ABL}$ & ++ & ++ \\
\hline Asteraceae & Ageratum conyzoides $\mathrm{L}$. & $\mathrm{ABL}$ & ++ & ++ \\
\hline Asteraceae & Tridax procumbens $\mathrm{L}$. & $\mathrm{ABL}$ & ++ & ++ \\
\hline Asteraceae & Aspilia africana (Pers) C.D. Adams & PBL & ++ & + \\
\hline Asteraceae & Chromoleana odorata Kings \& Robinson & PBL & +++ & +++ \\
\hline Asteraceae & Syndrella nodiflora Gaertn. & $\mathrm{ABL}$ & ++ & + \\
\hline Cucurbitaceae & Momordica charantia $\mathrm{L}$ & PBL & + & + \\
\hline Euphorbiaceae & Euphorbia heterophylla L. & $\mathrm{ABL}$ & +++ & +++ \\
\hline Euphorbiaceae & Euphorbia hirta $\mathrm{L}$ & $\mathrm{ABL}$ & +++ & +++ \\
\hline Euphorbiaceae & Phyllanthus amarus Schum. \&Thonn & $\mathrm{ABL}$ & ++ & + \\
\hline Fabaceae & Calopogonium mucunoides Desv & ABL & +++ & +++ \\
\hline Fabaceae & Mucuna pruriens (L.) DC & PBL & +++ & ++ \\
\hline Malvaceae & Sida acuta Burm F & PBL & ++ & ++ \\
\hline Malvaceae & Sida cordifolia Burm F & PBL & ++ & + \\
\hline Poaceae & Cynodon dactylon L. Pers & PG & +++ & ++ \\
\hline Poaceae & Digitaria horizontalis Willd & PG & ++ & ++ \\
\hline Poaceae & Eleusine indica (L.) Gaertn. & $\mathrm{AG}$ & ++ & ++ \\
\hline Poaceae & Panicum maximum Jacq. & PG & +++ & +++ \\
\hline Poaceae & Pennisetum purpureum $\mathrm{L}$ & PG & ++ & + \\
\hline Poaceae & Rottboellia cochinchinnensis Lour clayton & PG & ++ & ++ \\
\hline Portulacaceae & Talinum triangulare (Jacq.) Willd & PBL & ++ & ++ \\
\hline Cyperaceae & Cyperus escunlentus $\mathrm{L}$ & PS & ++ & ++ \\
\hline Cyperaceae & Cyperus rotundus $\mathrm{L}$. & PS & ++ & ++ \\
\hline Cyperaceae & Mariscus alternifolius Vahl & PS & + & ++ \\
\hline Cyperaceae & Mariscus flabelliformis $\mathrm{L}$ & PS & + & ++ \\
\hline
\end{tabular}

$[+]=$ low density; $[++]=$ medium density and $[+++]=$ high density. ABL=Annual broad leaf, PBL $=$ Perennial broad leaf, $\mathrm{AG}=$ Annual grass, $\mathrm{PS}=$ Perennial sedge.

Table 2. Effect of weed control practices on weed density (weed $/ \mathrm{m}^{2}$ ) of maize

\begin{tabular}{|l|l|l|l|l|}
\hline Treatment & 3WAP & $6 \mathrm{WAP}$ & $9 \mathrm{WAP}$ & $12 \mathrm{WAP}$ \\
\hline $\mathbf{2 0 0 4}$ & & & & \\
\hline No weeding (control) & $9.5 \mathrm{a}$ & $112.5 \mathrm{a}$ & $174.00 \mathrm{a}$ & $207.80 \mathrm{a}$ \\
\hline Primextra @ at 3.0kg a.i./ha & $0.00 \mathrm{~b}$ & $1.75 \mathrm{~d}$ & $10.00 \mathrm{~d}$ & $14.00 \mathrm{f}$ \\
\hline Mulching (wood shavings) & $0.00 \mathrm{~b}$ & $0.00 \mathrm{~d}$ & $2.75 \mathrm{e}$ & $7.50 \mathrm{~g}$ \\
\hline One hoe-weeding at 3WAP & $9.25 \mathrm{a}$ & $11.58 \mathrm{c}$ & $114.00 \mathrm{~b}$ & $125.20 \mathrm{c}$ \\
\hline Two hoe-weedings at 3 \&7WAP & $9.53 \mathrm{a}$ & $10.75 \mathrm{c}$ & $12.50 \mathrm{~d}$ & $40.70 \mathrm{e}$ \\
\hline Melon cover -crop (-Hoe-weeding) & $9.53 \mathrm{a}$ & $60.10 \mathrm{~b}$ & $50.60 \mathrm{c}$ & $129.50 \mathrm{~b}$ \\
\hline Melon cover -crop+Hoeweeding (3WAP) & $9.25 \mathrm{a}$ & $10.75 \mathrm{c}$ & $11.5 \mathrm{~d}$ & $51.70 \mathrm{~d}$ \\
\hline LSD (P=0.05) & 0.876 & 0.826 & 0.294 & 0.678 \\
\hline $\mathbf{2 0 0 5}$ & & & & \\
\hline No weeding (control) & $9.75 \mathrm{~b}$ & $114.25 \mathrm{a}$ & $177.50 \mathrm{a}$ & $213.80 \mathrm{a}$ \\
\hline
\end{tabular}


Effect of different weed control practices on proximate composition, nutrient concentration and ..

\begin{tabular}{|l|l|l|l|l|}
\hline Primextra ${ }^{\circledR}$ at 3.0kg a.i./ha & $0.00 \mathrm{c}$ & $1.25 \mathrm{~d}$ & $11.00 \mathrm{~d}$ & $15.00 \mathrm{f}$ \\
\hline Mulching (wood shavings) & $0.00 \mathrm{c}$ & $0.00 \mathrm{~d}$ & $3.50 \mathrm{f}$ & $8.50 \mathrm{~g}$ \\
\hline One hoe-weeding at 3WAP & $10.50 \mathrm{ab}$ & $10.00 \mathrm{c}$ & $116.00 \mathrm{~b}$ & $127.70 \mathrm{c}$ \\
\hline Two hoe-weedings at 3 \&7WAP & $10.25 \mathrm{ab}$ & $9.75 \mathrm{c}$ & $13.50 \mathrm{~d}$ & $46.50 \mathrm{e}$ \\
\hline Melon cover -crop (-Hoe-weeding) & $10.03 \mathrm{ab}$ & $58.75 \mathrm{~b}$ & $51.00 \mathrm{c}$ & $133.30 \mathrm{~b}$ \\
\hline Melon cover -crop+Hoeweeding (3WAP) & $10.75 \mathrm{a}$ & $10.25 \mathrm{c}$ & $12.5 \mathrm{e}$ & $58.67 \mathrm{~d}$ \\
\hline LSD $(\mathrm{P}=0.05)$ & 0.886 & 0.679 & 0.294 & 0.678 \\
\hline
\end{tabular}

Values followed by the same letter(s) in a column are not significantly different at 5\% level using LSD

Table3 . Effect of different weed control practices on proximate composition (\%) in maize grain

\begin{tabular}{|c|c|c|c|c|c|}
\hline Treatment/Year & Crude protein & Lipid & Crude ash & Crude fiber & Carbohydrate \\
\hline \multicolumn{6}{|l|}{2004} \\
\hline No weeding (control) & $13.62 \mathrm{f}$ & $4.56 \mathrm{f}$ & $2.70 \mathrm{~d}$ & $2.40 \mathrm{e}$ & $64.71 \mathrm{~g}$ \\
\hline 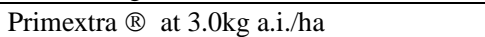 & $14.21 \mathrm{~b}$ & $4.75 b$ & $2.87 \mathrm{a}$ & $2.76 \mathrm{~b}$ & $78.15 \mathrm{~b}$ \\
\hline Mulching (wood shavings) & $14.44 \mathrm{a}$ & $4.86 \mathrm{a}$ & $2.91 \mathrm{a}$ & $2.80 \mathrm{a}$ & $79.28 \mathrm{a}$ \\
\hline One hoe-weeding at $3 \mathrm{WAP}$ & $14.07 \mathrm{~d}$ & $4.53 \mathrm{e}$ & $2.72 \mathrm{~d}$ & $2.61 \mathrm{~d}$ & $68.96 \mathrm{e}$ \\
\hline Two hoe-weedings at $3 \& 7 \mathrm{WAP}$ & $14.13 \mathrm{c}$ & $4.64 \mathrm{c}$ & $2.84 \mathrm{~b}$ & $2.71 \mathrm{c}$ & $78.06 \mathrm{c}$ \\
\hline Melon cover-crop (-Hoe-weeding) & $13.71 \mathrm{e}$ & $4.57 \mathrm{e}$ & $2.71 \mathrm{~d}$ & $2.43 \mathrm{e}$ & $64.84 \mathrm{f}$ \\
\hline Melon cover-crop+Hoeweeding (3WAP) & $14.06 \mathrm{~d}$ & $4.61 \mathrm{~d}$ & $2.76 \mathrm{c}$ & $2.70 \mathrm{c}$ & $78.04 \mathrm{~d}$ \\
\hline $\mathrm{LSD}(\mathrm{P}=0.05)$ & 0.005 & 0.004 & 0.004 & 0.004 & 0.013 \\
\hline \multicolumn{6}{|l|}{2005} \\
\hline No weeding (control) & $13.60 \mathrm{~d}$ & $4.43 \mathrm{c}$ & $2.64 \mathrm{c}$ & $2.35 \mathrm{e}$ & 64.31d \\
\hline Primextra $\AA$ at $3.0 \mathrm{~kg}$ a.i. $/ \mathrm{ha}$ & $14.12 \mathrm{~b}$ & $4.61 \mathrm{~b}$ & $2.83 \mathrm{a}$ & $2.71 \mathrm{~b}$ & $78.12 \mathrm{~b}$ \\
\hline Mulching (wood shavings) & $14.43 \mathrm{a}$ & $4.82 \mathrm{a}$ & $2.85 \mathrm{a}$ & $2.80 \mathrm{a}$ & $79.21 \mathrm{a}$ \\
\hline One hoe-weeding at 3WAP & $14.06 \mathrm{~b}$ & $4.50 \mathrm{~b}$ & $2.71 \mathrm{~b}$ & $2.60 \mathrm{c}$ & $68.94 \mathrm{~d}$ \\
\hline Two hoe-weedings at $3 \& 7 \mathrm{WAP}$ & $14.10 \mathrm{~b}$ & $4.60 \mathrm{~b}$ & $2.81 \mathrm{a}$ & $2.69 \mathrm{~b}$ & $78.03 \mathrm{c}$ \\
\hline Melon cover -crop (-Hoe-weeding) & $13.69 \mathrm{c}$ & $4.56 \mathrm{~b}$ & $2.70 \mathrm{~b}$ & $2.41 \mathrm{~d}$ & $64.80 \mathrm{e}$ \\
\hline Melon cover - crop+Hoeweeding ( $3 \mathrm{WAP}$ ) & $14.05 \mathrm{~b}$ & $4.60 \mathrm{~b}$ & $2.73 \mathrm{~b}$ & $2.70 \mathrm{~b}$ & $78.01 \mathrm{c}$ \\
\hline $\operatorname{LSD}(\mathrm{P}=0.05)$ & 0.008 & 0.004 & 0.005 & 0.004 & 0.004 \\
\hline
\end{tabular}

Values followed by the same letter(s) in a column are not significantly different at 5\% level using LSD

Table 4. Effect of different weed control practices on ear leaf dry weight $(\mathrm{kg} / \mathrm{ha})$ and nutrient concentration (\%) in ear leaf of maize

\begin{tabular}{|c|c|c|c|c|c|c|c|}
\hline Treatment/Year & $\begin{array}{l}\text { Ear leaf dry } \\
\text { weight) }\end{array}$ & $\mathrm{N}$ & $\mathrm{P}$ & $\mathrm{K}$ & $\mathrm{Ca}$ & $\mathrm{Mg}$ & $\mathrm{Na}$ \\
\hline \multicolumn{8}{|l|}{2004} \\
\hline No weeding (control) & $1063.66 \mathrm{~g}$ & $0.41 \mathrm{c}$ & $0.20 \mathrm{~g}$ & $1.98 \mathrm{a}$ & $0.22 \mathrm{~g}$ & $0.23 \mathrm{~g}$ & $0.37 \mathrm{~b}$ \\
\hline Primextra $\AA$ at $3.0 \mathrm{~kg}$ a.i. $/ \mathrm{ha}$ & $1962.65 b$ & $1.95 \mathrm{~b}$ & $0.36 \mathrm{~b}$ & $2.31 \mathrm{a}$ & $0.36 \mathrm{~b}$ & $0.41 \mathrm{~b}$ & $0.79 \mathrm{a}$ \\
\hline Mulching wood shavings & $1973.32 \mathrm{a}$ & $2.79 a$ & $0.38 \mathrm{a}$ & $2.38 \mathrm{a}$ & $0.50 \mathrm{a}$ & $0.49 \mathrm{a}$ & $1.18 \mathrm{a}$ \\
\hline One hoe-weeding at $3 \mathrm{WAP}$ & $1202.13 \mathrm{e}$ & $0.79 \mathrm{c}$ & $0.28 \mathrm{~d}$ & $2.04 a$ & $0.25 \mathrm{e}$ & $0.30 \mathrm{~d}$ & $0.47 \mathrm{~b}$ \\
\hline Two hoe-weedings at $3 \& 7 \mathrm{WAP}$ & $1902.99 \mathrm{c}$ & $0.98 \mathrm{c}$ & $0.30 \mathrm{c}$ & $2.10 \mathrm{a}$ & $0.30 \mathrm{c}$ & $0.36 \mathrm{c}$ & $0.71 \mathrm{a}$ \\
\hline Melon cover -crop (-Hoe-weeding) & $1071.99 \mathrm{f}$ & $0.50 \mathrm{c}$ & $0.23 \mathrm{f}$ & $2.00 \mathrm{a}$ & $0.23 \mathrm{f}$ & $0.24 \mathrm{f}$ & $0.38 \mathrm{~b}$ \\
\hline $\begin{array}{l}\text { Melon cover -crop+Hoeweeding } \\
\text { (3WAP) }\end{array}$ & $1317.12 \mathrm{~d}$ & $0.80 \mathrm{c}$ & $0.26 \mathrm{e}$ & $2.09 \mathrm{a}$ & $0.28 \mathrm{~d}$ & $0.34 \mathrm{e}$ & $0.67 \mathrm{ab}$ \\
\hline $\operatorname{LSD}(\mathrm{P}=0.05)$ & 0.391 & 0.808 & 0.004 & 0.675 & 0.004 & 0.004 & 0.61 \\
\hline \multicolumn{8}{|l|}{2005} \\
\hline No weeding (control) & $978.66 \mathrm{~g}$ & $0.40 \mathrm{~b}$ & $0.19 \mathrm{~g}$ & $1.95 \mathrm{a}$ & $0.21 \mathrm{~g}$ & $0.20 \mathrm{~g}$ & $0.36 \mathrm{~b}$ \\
\hline Primextra ${ }^{\circledR}$ at $3.0 \mathrm{~kg}$ a.i./ha & $1930.45 b$ & $1.90 \mathrm{a}$ & $0.35 b$ & $2.30 \mathrm{a}$ & $0.36 \mathrm{~b}$ & $0.40 \mathrm{~b}$ & $0.78 \mathrm{a}$ \\
\hline Mulching ( wood shavings) & $1946.65 a$ & $2.61 \mathrm{a}$ & $0.37 \mathrm{a}$ & $2.38 \mathrm{a}$ & $0.48 \mathrm{a}$ & $0.47 \mathrm{a}$ & $1.17 \mathrm{a}$ \\
\hline One hoe-weeding at 3WAP & $1178.84 \mathrm{e}$ & $0.76 b$ & $0.27 \mathrm{~d}$ & $2.04 \mathrm{a}$ & $0.25 \mathrm{e}$ & $0.23 \mathrm{e}$ & $0.46 \mathrm{~b}$ \\
\hline Two hoe-weedings at $3 \& 7 \mathrm{WAP}$ & $1878.32 \mathrm{c}$ & $0.92 b$ & $0.29 \mathrm{c}$ & $2.09 \mathrm{a}$ & $0.29 \mathrm{c}$ & $0.33 \mathrm{c}$ & $0.70 \mathrm{a}$ \\
\hline Melon cover -crop (-Hoe-weeding) & $1013.33 \mathrm{f}$ & $0.49 \mathrm{~b}$ & $0.22 \mathrm{f}$ & $1.97 \mathrm{a}$ & $0.22 \mathrm{f}$ & $0.22 \mathrm{f}$ & $0.38 \mathrm{~b}$ \\
\hline $\begin{array}{l}\text { Melon cover -crop+Hoeweeding } \\
\text { (3WAP) }\end{array}$ & $1280.32 \mathrm{~d}$ & $0.78 b$ & $0.25 \mathrm{e}$ & $2.07 \mathrm{a}$ & $0.26 \mathrm{~d}$ & $0.27 \mathrm{~d}$ & $0.66 \mathrm{ab}$ \\
\hline $\operatorname{LSD}(\mathrm{P}=0.05)$ & 0.391 & 0.787 & 0.004 & 1.254 & 0.004 & 0.004 & 0.61 \\
\hline
\end{tabular}

Values followed by the same letter(s) in a column are not significantly different at 5\% level using LSD

Table 5. Effect of different weed control practices on nutrient uptake $(\mathrm{kg} / \mathrm{ha})$ in ear leaf of maize

\begin{tabular}{|l|l|l|l|l|l|l|}
\hline Treatment/Year & $\mathrm{N}$ & $\mathrm{P}$ & $\mathrm{K}$ & $\mathrm{Ca}$ & $\mathrm{Mg}$ & $\mathrm{Na}$ \\
\hline $\mathbf{2 0 0 4}$ & & & & & & \\
\hline No weeding (control) & $4.36 \mathrm{c}$ & $2.13 \mathrm{~d}$ & $21.06 \mathrm{~b}$ & $2.34 \mathrm{e}$ & $2.44 \mathrm{~g}$ & $3.94 \mathrm{~b}$ \\
\hline Primextra $\otimes$ at 3.0kg a.i./ha & $38.27 \mathrm{~b}$ & $7.06 \mathrm{a}$ & $45.33 \mathrm{a}$ & $7.07 \mathrm{~b}$ & $8.05 \mathrm{~b}$ & $15.51 \mathrm{a}$ \\
\hline Mulching (wood shavings) & $55.06 \mathrm{a}$ & $7.50 \mathrm{a}$ & $46.96 \mathrm{a}$ & $9.87 \mathrm{a}$ & $9.67 \mathrm{a}$ & $23.29 \mathrm{a}$ \\
\hline One hoe-weeding at 3WAP & $9.10 \mathrm{c}$ & $3.37 \mathrm{c}$ & $24.53 \mathrm{~b}$ & $3.01 \mathrm{c}$ & $3.61 \mathrm{f}$ & $5.65 \mathrm{~b}$ \\
\hline Two hoe-weedings at3 \&7WAP & $18.62 \mathrm{c}$ & $5.71 \mathrm{~b}$ & $39.96 \mathrm{a}$ & $5.71 \mathrm{~d}$ & $6.85 \mathrm{c}$ & $13.52 \mathrm{a}$ \\
\hline Melon cover -crop (-Hoe-weeding) & $5.36 \mathrm{c}$ & $2.47 \mathrm{~d}$ & $21.44 \mathrm{~b}$ & $2.47 \mathrm{e}$ & $2.57 \mathrm{e}$ & $4.07 \mathrm{~b}$ \\
\hline Melon cover-crop+Hoeweeding (3WAP) & $10.53 \mathrm{c}$ & $3.42 \mathrm{c}$ & $27.52 \mathrm{~b}$ & $3.73 \mathrm{c}$ & $4.52 \mathrm{~d}$ & $8.87 \mathrm{~b}$ \\
\hline LSD (P=0.05) & 16.46 & 0.761 & 12.78 & 0.761 & 0.761 & 12.431 \\
\hline
\end{tabular}


Effect of different weed control practices on proximate composition, nutrient concentration and ..

\begin{tabular}{|l|l|l|l|l|l|l|}
\hline $\mathbf{2 0 0 5}$ & & & & & \\
\hline No weeding (control) & $3.95 \mathrm{~d}$ & $1.86 \mathrm{~d}$ & $19.08 \mathrm{c}$ & $2.06 \mathrm{e}$ & $1.96 \mathrm{e}$ & $3.52 \mathrm{~b}$ \\
\hline Primextra $\circledR$ at 3.0kg a.i./ha & $36.68 \mathrm{~b}$ & $6.76 \mathrm{a}$ & $44.40 \mathrm{a}$ & $6.95 \mathrm{~b}$ & $7.72 \mathrm{~b}$ & $15.06 \mathrm{a}$ \\
\hline Mulching (wood shavings) & $54.12 \mathrm{a}$ & $7.20 \mathrm{a}$ & $46.33 \mathrm{a}$ & $9.34 \mathrm{a}$ & $9.15 \mathrm{a}$ & $22.78 \mathrm{a}$ \\
\hline One hoe-weeding at 3WAP & $8.96 \mathrm{~d}$ & $3.18 \mathrm{c}$ & $24.04 \mathrm{c}$ & $2.95 \mathrm{~d}$ & $2.71 \mathrm{~d}$ & $5.42 \mathrm{~b}$ \\
\hline Two hoe-weedings at 3 \&7WAP & $22.91 \mathrm{bc}$ & $5.45 \mathrm{~b}$ & $39.26 \mathrm{~b}$ & $5.45 \mathrm{c}$ & $6.20 \mathrm{c}$ & $13.15 \mathrm{ab}$ \\
\hline Melon cover -crop (-Hoe-weeding) & $4.97 \mathrm{~d}$ & $2.23 \mathrm{~d}$ & $19.96 \mathrm{c}$ & $2.23 \mathrm{e}$ & $2.23 \mathrm{e}$ & $3.85 \mathrm{~b}$ \\
\hline Melon cover -crop+Hoeweeding (3WAP) & $10.03 \mathrm{~cd}$ & $3.20 \mathrm{c}$ & $26.51 \mathrm{bc}$ & $3.37 \mathrm{~d}$ & $3.51 \mathrm{~d}$ & $8.49 \mathrm{~b}$ \\
\hline LSD (P =0.05) & 15.944 & 0.795 & 14.829 & 0.789 & 0.790 & 12.281 \\
\hline
\end{tabular}

Values followed by the same letter(s) in a column are not significantly different at 5\% level using LSD

Table 6.Effect of different weed control practices on nutrient concentration (\%) in maize grain

\begin{tabular}{|c|c|c|c|c|c|c|}
\hline Treatment/Year & $\mathrm{N}$ & $\mathrm{P}$ & $\mathrm{K}$ & $\mathrm{Ca}$ & $\mathrm{Mg}$ & $\mathrm{Na}$ \\
\hline \multicolumn{7}{|l|}{2004} \\
\hline No weeding (control) & $2.40 \mathrm{e}$ & $0.19 \mathrm{e}$ & $0.18 \mathrm{~g}$ & $0.27 \mathrm{~g}$ & $0.10 \mathrm{f}$ & $0.19 \mathrm{~g}$ \\
\hline Primextra $\AA$ at $3.0 \mathrm{~kg}$ a.i. $/ \mathrm{ha}$ & $2.71 \mathrm{~b}$ & $0.26 \mathrm{a}$ & $0.24 \mathrm{~b}$ & $0.34 \mathrm{~b}$ & $0.16 \mathrm{~b}$ & $0.25 \mathrm{~b}$ \\
\hline Mulching (wood shavings) & $2.92 \mathrm{a}$ & $0.27 \mathrm{a}$ & $0.25 \mathrm{a}$ & $0.36 \mathrm{a}$ & $0.17 \mathrm{a}$ & $0.26 \mathrm{a}$ \\
\hline One hoe-weeding at 3WAP & $2.48 \mathrm{~d}$ & $0.22 \mathrm{c}$ & $0.21 \mathrm{e}$ & $0.30 \mathrm{e}$ & $0.14 \mathrm{~d}$ & $0.22 \mathrm{e}$ \\
\hline Two hoe-weedings at $3 \& 7 \mathrm{WAP}$ & $2.59 \mathrm{c}$ & $0.24 \mathrm{~b}$ & $0.23 \mathrm{c}$ & $0.32 \mathrm{c}$ & $0.15 \mathrm{c}$ & $0.24 \mathrm{c}$ \\
\hline Melon cover -crop (-Hoe-weeding) & $2.42 \mathrm{e}$ & $0.23 b c$ & $0.20 \mathrm{f}$ & $0.29 \mathrm{f}$ & $0.13 \mathrm{e}$ & $0.21 \mathrm{f}$ \\
\hline Melon cover-crop+Hoeweeding (3WAP) & $2.55 \mathrm{c}$ & $0.21 \mathrm{~d}$ & $0.22 \mathrm{~d}$ & $0.31 \mathrm{~d}$ & $0.14 \mathrm{~d}$ & $0.23 \mathrm{~d}$ \\
\hline $\operatorname{LSD}(\mathrm{P}=0.05)$ & 0.053 & 0.011 & 0.008 & 0.007 & 0.007 & 0.004 \\
\hline \multicolumn{7}{|l|}{2005} \\
\hline No weeding (control) & $2.39 \mathrm{e}$ & $0.18 \mathrm{~d}$ & $0.17 \mathrm{f}$ & $0.26 \mathrm{f}$ & $0.09 \mathrm{~g}$ & $0.18 \mathrm{~g}$ \\
\hline Primextra $\AA$ at $3.0 \mathrm{~kg}$ a.i. $/ \mathrm{ha}$ & $2.70 \mathrm{~b}$ & $0.25 \mathrm{a}$ & $0.23 \mathrm{~b}$ & $0.33 \mathrm{~b}$ & $0.15 b$ & $0.24 \mathrm{~b}$ \\
\hline Mulching( wood shavings) & $2.91 \mathrm{a}$ & $0.26 \mathrm{a}$ & $0.24 \mathrm{a}$ & $0.34 \mathrm{a}$ & $0.16 \mathrm{a}$ & $0.25 \mathrm{a}$ \\
\hline One hoe-weeding at 3WAP & $2.46 \mathrm{~d}$ & $0.22 \mathrm{~b}$ & $0.19 \mathrm{e}$ & $0.27 \mathrm{e}$ & $0.13 \mathrm{~d}$ & $0.21 \mathrm{e}$ \\
\hline Two hoe-weedings at $3 \& 7 \mathrm{WAP}$ & $2.57 \mathrm{c}$ & $0.23 \mathrm{~b}$ & $0.22 \mathrm{c}$ & $0.30 \mathrm{c}$ & $0.14 \mathrm{c}$ & $0.23 \mathrm{c}$ \\
\hline Melon cover-crop (-Hoe-weeding) & $2.40 \mathrm{~d}$ & $0.22 \mathrm{~b}$ & $0.19 \mathrm{e}$ & $0.29 \mathrm{~d}$ & $0.11 \mathrm{f}$ & $0.20 \mathrm{f}$ \\
\hline Melon cover-crop+Hoeweeding (3WAP) & $2.54 \mathrm{c}$ & $0.20 \mathrm{c}$ & $0.21 \mathrm{~d}$ & $0.30 \mathrm{c}$ & $0.12 \mathrm{e}$ & $0.22 \mathrm{~d}$ \\
\hline $\operatorname{LSD}(\mathrm{P}=0.05)$ & 0.061 & 0.010 & 0.008 & 0.008 & 0.007 & 0.004 \\
\hline
\end{tabular}

Values followed by the same letter(s) in a column are not significantly different at 5\% level using LSD

\section{Reference}

[1]. S.U. Remison, Arable and Vegetable Crops of the tropics, (Gift Print Associates, City. 2005) 4-5

[2]. P,Tunku, D.B Ishaya, and M. Haruna, Evaluation of a new herbicide formulation Integrity ${ }^{\mathrm{TM}}$ for weed control in extra early maize (Zea may L.), Weed Science Society of Nigeria 29, 2016, 32 -40

[3]. A.O. Ujabadeniyi, and J.T, Adebolu, The effect of processing method on nutritional properties of ogi produced from three maize varieties. J. Food,Agric and Environment, 2005, 3:108-109.

[4]. E .I, Sule, I, Umoh ,V.J. Whong, C.M.Z, I.O Abdullahi,.O Alabi, Chemical and nutritional value of maize and maize products obtained from selected markets in Kaduna State, Nigeria, African Journal of Food Science and Technology 5(4), 2014,100-104

[5]. O.L Oke ,Chemical Studies on Some Nigerian Cereals, Cereal Chemistry 42, 1965, 299- 302.

[6]. M.A. Mahadi, Growth, nutrient uptake and yield of maize (Zea mays L.) as influenced by weed control and poultry manure I.J.S.N. 5 (1), 2014,94-102

[7]. I.O Akobundu and F. Ekeleme, Effect of Imperata cylindrica management on maize grain yield in the derived . Weed Research40, $2000,335-341$.

[8]. S.T.O .Lagoke, J.O., Adeosun., K.A., Elemo, V.O Chude, and J.A.Y Shebayan, Herbicide evaluation for the control of weeds in maize at Samaru. In Report on cereals research scheme meeting held at IAR/ABU.Samaru, 1998, 90-91

[9]. J. A. Adepetu; A.A, Adebayo, E.A Aduayi, and C.O Alofe, A preliminary survey the fertility Status of soils in Ondo State under traditional Cultivation, Ife Journal of 1,1986, 134-149

[10]. R.A Sobulo,. and A.O Osiname, Soils and Fertilizer use in Western Nigeria (University of Ife, Institute of Agriculture and training Research Bulletin 11, 1981)

[11]. I.O. Akobundu. and C.W Agyakwa, A Handbook of West African Weeds, (International Institute of Tropical Agriculture, Ibadan, Nigeria, 1987, 521)

[12]. AOAC(Association of official Analytical Chemist), Official Method of Analysis (15 ${ }^{\text {th }}$ edition. Washigton, D.C., USA, 1990)

[13]. K Ali, F. Munsif, Z.I Husain, I Khan, N Ahmad N Khan and M. Shahid, Effect of different weed control methods on weeds and maize grain yield, Pak. J. Weed sci. res. 17(4), 2011, 313-321

[14]. E.M. Ossom, P.F Pace, R.L. Rhykerd, and C.L. Rhykerd, Effect of mulch on weed infestation, soil temperature, nutrient concentration, and tuber yield in Ipomoea batatus (L.) Lam. In Papua New Guinea. Trop. Agric. (Trinidad) 78, 2001, 144-151

[15]. A. Mehmeti, A. Demaj, I. Demelezi, and H. Rudari, Effect Of Post-Emergence Herbicides On Weeds and Yield Of Maize, Pak. J. Weed Sci. Res. 18 (1), 2012,27-

[16]. I .M El - Metwally, and S.A Saad El-Din, Response of pea (Pisum sativum L.) plants to some weed control treatments, J. Agric. Sc. 28(2), 2003, 947-969.

[17]. J. Jones, and H. V Eck, Plant analysis as an aid in fertilizing corn and grain sorghum in Walsh, L. M. Beaton, J. D. eds. Soil testing and plant analysis. Soil Science Society of America, International Conference, Madison, Wisconsin, USA, 1973,349-364.

[18]. C. S. Shrinivas, A. S Channabasavanna, and S. R, Mallikarjun, Evaluation of sequential application of herbicides on nutrient uptake and yield of maize (Zea mays L.) under irrigated condition, Research Journal of Agricultural Sciences 5(5), 2014, 24-926. 